\title{
前方から一期的に摘出しえた頚椎砂時計腫の一例
}

\author{
山城 和 馬 ${ }^{*}$ 瀬 井章* 藤 本 徹* \\ 水 溜 正 也* 谷脇 琭 也* ${ }^{*}$ 水 田 博 志*
}

\section{Total Removal Achieved by the Single-Stage Anterior Approach for Cervical Dumbbell Tumor : A Case Report}

\author{
Kazuma Yamashiro*, Akira Sei*, Toru Fujimoto*, Masaya Mizutamari*, \\ Takuya Taniwaki*, and Hiroshi Mizuta*
}

\begin{abstract}
頚椎砂時計腫は，形態よって手術手技が異なる。前方から一期的に摘出しえた頝椎砂時計腫を経験した ので報告する。症例は 75 歳の女性であった。約 4 年前より左頚部に腫瘤を認め, 腫瘤の増大と, 腫瘤圧 迫による左手指の痺れを自覚するようになり当科を紹介され受診した。左頚部に径 $4 \mathrm{~cm}$ の弾性硬の腫瘤 を認め，圧迫にて左第 2-5 指に痺れを認めた。画像検査上，戸山らの形態分類にて Type II b の砂時計腫 を認めた．手術は前方よりアプローチし，一期的に全摘出が可能であった。病理組織診断は神経鞘腫であっ た。本症例のように椎間孔の拡大が顕著で，春柱管内の病巣が大きくないものは，戸山の Type II bでも 前方より一期的に摘出が可能である.
\end{abstract}

OBJECTIVE: We report a case of cervical dumbbell tumor that was totally removed by the single-stage anterior approach.

CLINICAL PRESENTATION: The patient was a 75-year-old woman presenting signs of C7 radiculopathy on the left side. Computed tomographic scan (CT) and magnetic resonance imaging (MRI) demonstrated a dumbbell tumor that had developed through the C6-7 interventebral foramen. INTERVATION: The tumor was totally removed by the single-stage anterior approach, with control of the vertebral artery. Pathological examination revealed schwannoma. Three months later, neurological examination results were normal, and MRI revealed complete tumor resection.

CONCLUSION: We believe that the anterior approach is effective for total single-stage tumor removal in selected cases of cervical dumbell type schwannoma with large extension through the wide intervertebral foramen.

Key words : cervical dumbbell tumors (頝椎砂時計腫), schwannoma (神経鞘腫), anterior approach (前方進入)

\section{は じめ に}

頚椎砂時計腫は，脊椎脊䯣や椎骨動脈との位置関係 によって手術手技やアプローチが異なる，前方から一 期的に摘出しえた頚椎砂時計腫を経験したので, 若干 の文献的考察を加えて報告する.

\section{症例}

75 歳の女性. 既往歴に特記事項なし. 約 4 年前よ り左頚部に腫瘤を自覚するようになった。徐々に腫瘤 が増大し，腫瘤を圧迫すると左手指の痺れを自覚する
ようになったため, 当科を紹介され受診した。

身体所見では, 左頚部に径 $4 \mathrm{~cm}$ の弾性硬, 可動性 不良な腫瘤を触知した。腫瘤を圧すると左第 2,3 指 に放散痛を認めた。左手関節より末梢に 6/10 程度の 感覚鈍麻を認めたが，筋力低下や深部腱反射異常はな かった。

頝椎の単純レントゲンでは, C6-7レベルにて左椎 間孔の拡大と C6-7 椎体の scalloping を認めた（図 1). 頚椎単純 $\mathrm{CT}$ では, C7 レベルの脊柱管から左頚部に かけて約 $4 \times 6 \mathrm{~cm}$ の腫瘍性病変を認めた。 また, そ れにより椎間孔は拡大し, 菲薄化した椎間関節の一部

\footnotetext{
* 熊本大学大学院医学薬学研究部運動骨格病態学分野 Department of Orthopedic and Neuro-Musculoskeletal Surgery, Faculty of Medical and Pharmaceutical Sciences, Kumamoto University, Kumamoto, Japan
} 

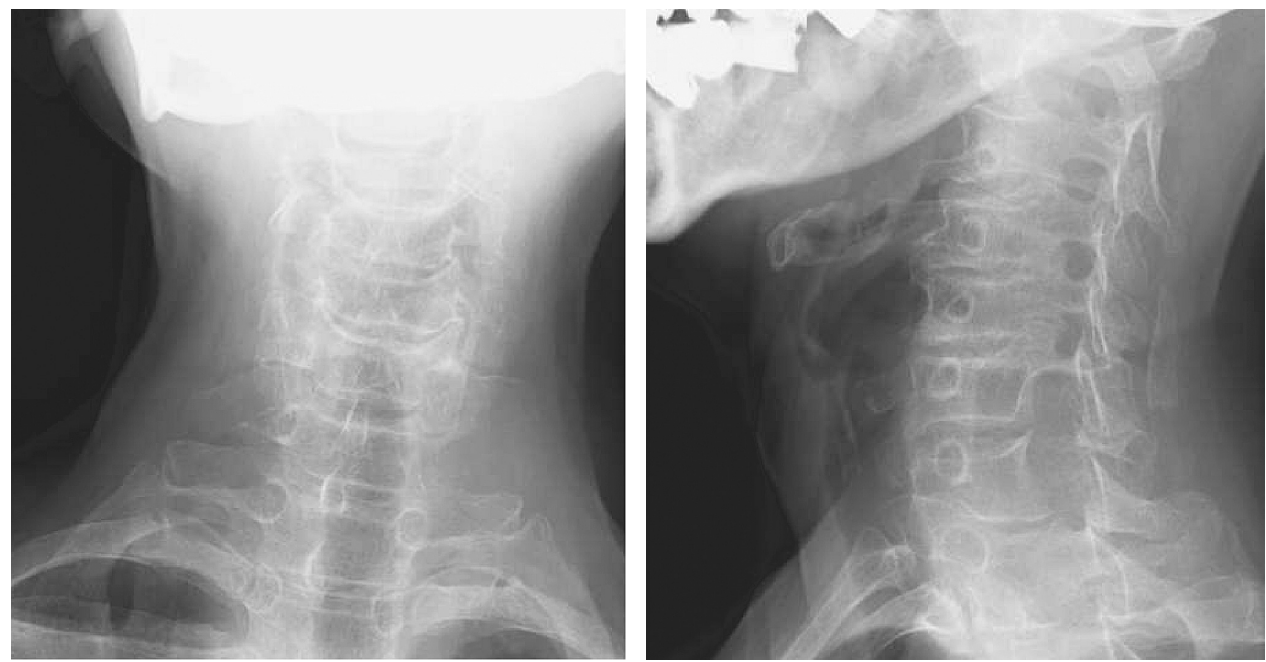

図 1 頸椎単純 $\mathrm{X}-\mathrm{p}$

C6-7 レベルにて左椎間孔の拡大（左）とC6-7 椎体の scalloping（右）を認めた.
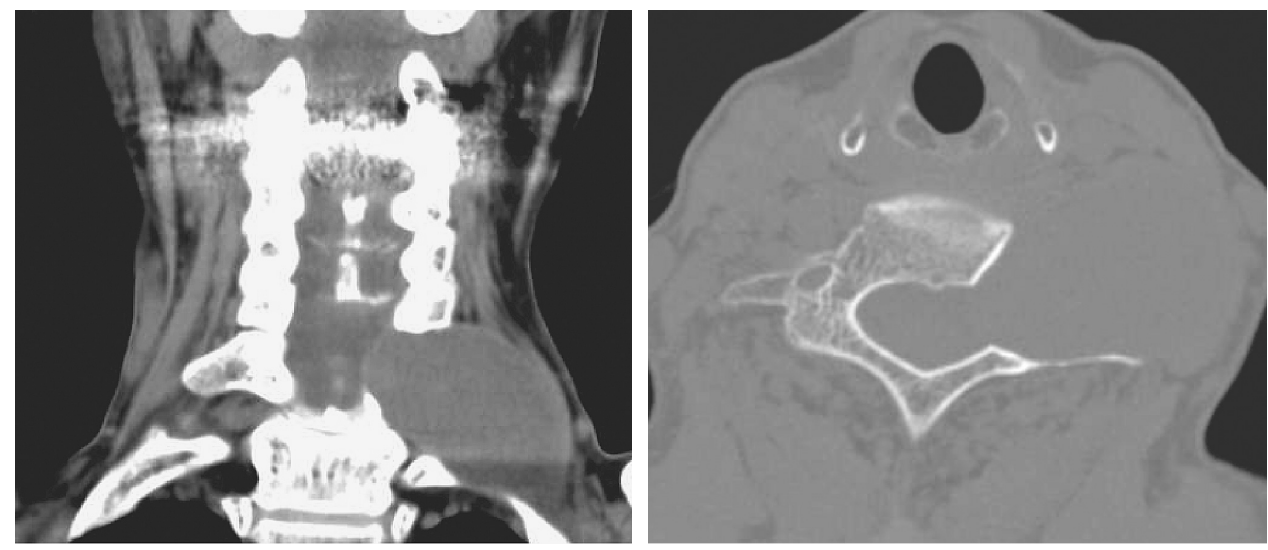

図 2 頸椎 $\mathrm{CT}$

$\mathrm{C} 7$ レベルの脊柱管から左頚部にかけて約 $4 \times 6 \mathrm{~cm}$ の腫瘍性病变を認め, それ により椎間孔は拡大し，菲薄化した椎間関節の一部を認めた。

を認めた（図 2 )。造影 MRI では，同部位に T1 強調 画像で low，T2 強調画像で high を呈する境界明瞭な 腫瘍性病変を認め, 一部は春柱管内に突出していた。 また，左椎骨動脈は病変によって圧迫され前方に偏位 していた (図 3 )。画像所見より，戸山らの形態分 類 ${ }^{1{ }^{5)}}$ にて Type IIb に分類される砂時計型神経鞘腫 が疑われた。

手術は前方からアプローチした。左椎骨動脈を同定 しこれを剥離した上で，内減圧を行いながら被膜ごと
摘出術を行った。椎間孔が腫瘍により拡大しており, 椎間孔内の操作は比較的容易であった。病理組織学的 診断は神経鞘腫であった。

術後 3 ヶ月時の診察では, 左手指のしびれが残存す るものの軽快傾向にあり，新たな神経脱落症状などの 合併症は認めなかった。 また, 頚椎アライメントの変 化は認めなかった。単純 CT では，C6/7 の左椎間孔 は拡大したままであるが椎間関節は保たれていた。 MRI では，腫瘍の存在していた部位に疲痕組織の増 

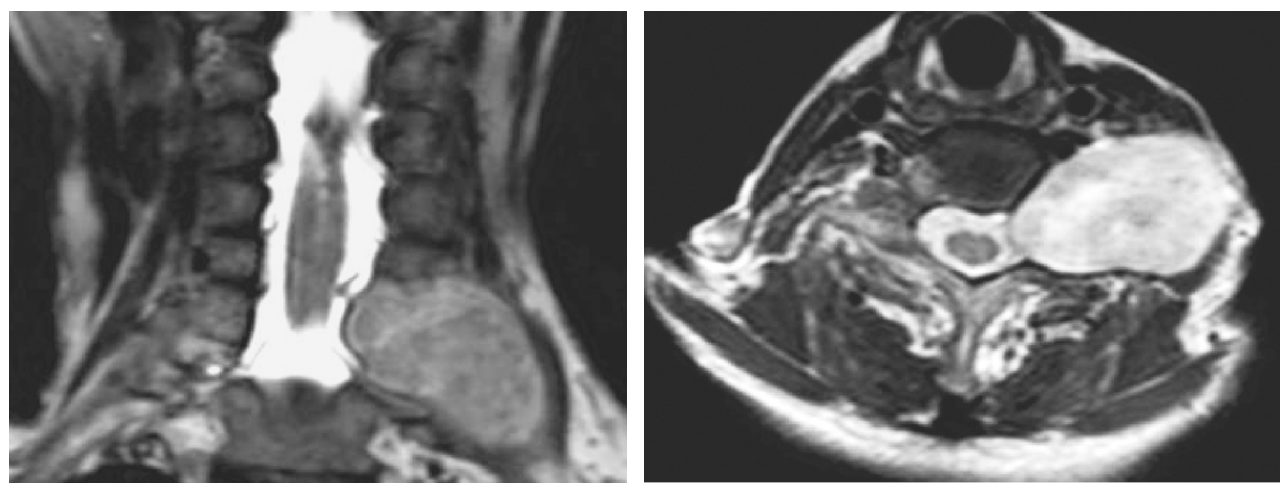

図 3 頸椎 MRI

境界明瞭な腫瘍性病変を認め, 一部は脊柱管内に突出していた。 また，左椎骨 動脈は病变によって圧迫され前方に偏位していた。

生を認め，それにより左椎骨動脈は半円状に取り囲ま れているが, 明らかな圧迫, 偏位は認めなかった。

考察

頚椎砂時計腫は神経鞘腫や神経線維腫など良性であ ることが多い3). しかし，腫瘍の大きさや位置によっ てアプローチを変える必要があり, 特に腫瘍と椎骨動 脈之の位置関係が重要になる ${ }^{2)}$.

戸山らは砂時計型腫瘍を 6 タイプに分類し，それに 基づいたアプローチ法を提示している ${ }^{15)}$. 当科では Type I, II a, III に に対しては後方から， II cに対し ては前方からアプローチし， II b， IIIbに対しては前 後方合併法を用いている。通常, Type II bの腫瘍に 対しては，まず後方アプローチを行い春柱管内ならび に椎間孔内の腫瘍を摘出し, 次いで前方より残存腫瘍 を摘出している. 本症例は脊柱管内の腫瘍が小さく, 椎間孔の拡大む顕著であったことより, 前方からの一 期的摘出術が可能と判断した。椎間孔外の神経鞘腫に ついては, 神経外膜之皮膜間は結合が比較的粗であり, また椎骨動脈は外膜外に存在するため，椎骨動脈を同 定・剥離し, 術中迅速病理検査にて神経鞘腫の診断を 得た後に内減圧を行い, その皮膜を牽引しながら皮膜
外膜間で剥離を進めることにより, 全摘出が可能であ る.

ま と め

前方より一期的に摘出しえた頚椎砂時計腫を経験し た. 椎間孔の拡大が顕著で, 脊柱管内の病変が大きく ないものは, 戸山の形態分類 Type II b でも前方より

一期的に摘出が可能である.

\section{参 考 文 献}

1) Asazuma, T., et al. : Surgical Strategy for Cervical Dumbbell Tumors Based on a Three-dimensional Classification. Spine, 29 : E10-E14, 2004.

2) Iwasaki, Y., et al. : Anterior Approach for Dumbbell Type Cervical Neurinoma. Neurol. Med. Chir., 39 : 835-840, 1999.

3) Lot, G., George, B. : Cervical Neuromas with Extradural Components: Surgical Management in a Series of 57 Patients. Neurosurgery, 41 : 813-822, 1997.

4) McCormick, P. C.: Surgical Management of Dumbbell Tumors of the Cervical Spine. Neurosurgery, 38 : 294-300, 1996.

5）戸山芳昭他：脊䯣砂時計腫 83 例の検討一新形態分類之 手術法について一。日本パラプレジア医学会誌, $5: 86-87,1991$. 